ISSN: $1231-4005$

e-ISSN: $2354-0133$

DOI: $10.2478 /$ kones-2019-0048

\title{
THE IMPACT OF A PLACE FOR THE MEASUREMENT OF CYLINDER PRESSURE OF MARINE PISTON ENGINE ON THE INDICATOR DIAGRAMS AND INDICATOR PARAMETERS
}

\author{
Kazimierz Witkowski, Jacek Wysocki \\ Gdynia Maritime University \\ Faculty of Marine Engineering \\ tel.: 585586430,585586439 \\ e-mail:k.witkowski@wm.umg.edu.pl,j.wysocki@wm.umg.edu.pl
}

\begin{abstract}
The article discusses one of the most popular methods of diagnosing selected damages of marine piston engines, which is the indication or measurement of pressure changes in the engine's combustion chamber. Improving the quality of indicator diagrams may contribute to the increase in the efficiency of using the parameters indicated in the diagnostics of marine piston engines. Measurement errors during engine indication are primarily caused by measuring channels that connect the combustion chamber to the pressure sensor. One way to avoid these errors is to install the pressure sensor directly in the combustion chamber. It seems that it is possible to eliminate these errors. However, there is a risk that the pressure sensor will be damaged by the effect of high temperature on it during combustion of the fuel-air mixture in the engine's combustion chamber. The article presents the results of tests that indicate that the measured temperatures in the place where the sensor was installed (in the combustion chamber) did not exceed the critical value specified by the pressure sensor manufacturer. The article also presents the results of cylinder pressure measurement not only in the combustion chamber but also in two other points - on the thread of the indicator cock and in the measuring channel between the indicator cock and the cylinder head. The tests were carried out in a wide range of engine load technically efficient and with simulated damage in the fuel injection system. The article presents a comparative analysis of the parameters read out of the indicator diagram for the three abovementioned pressure measurement locations. It was shown that the pressure measurements carried out directly in the combustion chamber are free from errors resulting from the influence of measuring channels and indicator cock.
\end{abstract}

Keywords: diagnostics, marine piston engines, self-ignition engines, indication, middle indicated pressure, combustion pressure

\section{Introduction}

Propulsion systems for cargo ships and their power plants designed and built nowadays are based primarily on the use of charged, compression ignition of piston engines. The operation of these engines is very difficult. On the one hand, this is due to the fact that in recent years the ecological requirements set by the International Maritime Organization (IMO) for designers, builders and ship owners increased significantly. This applies, among others, to greenhouse gas emissions, sulphur and nitrogen compounds, and solid contaminants to the atmosphere, as described in Annex VI of the MARPOL Convention. The aim is also to increase the energy efficiency of the ship, which is associated with the reduction of greenhouse gas emissions. The increasing power demand causes the ship piston engines generating higher costs of use and higher cost of operation. Further requirements for the ship's propulsion systems and ship power plants are the safety of navigation and operation. On the other hand, poor quality fuels are often used to look for savings. Ships are intensively exploited often without the necessary diagnostics, inspections, adjustments or repairs. All the conditions and requirements mentioned above force the use of security systems, monitoring and diagnostics systems for naval piston engines. One of the most popular and accurate methods of diagnosing marine engines apart from measurements and inspections is the engine's indication. The advantage of this method is that it does not require 
stopping the engine. It is based on measuring the cylinder pressure of the running engine and helps in determining the current technical condition of injection equipment, charge system, and exchange of charge and tightness of the combustion chamber. In recent years, electronic indicators have been used to evaluate the technical condition of the above-mentioned systems. Indicator charts prepared with the use of electronic indicators are the basic source of diagnostic information. Electronic indicator software allows reading indicative parameters. In some electronic indicators, the option of measuring the pressure of fuel injection is offered, but for reasons of fire safety on ships, the measurement of fuel injection pressure is not commonly used. The improvement of the diagnostics status of marine engines can be obtained by increasing the quality (accuracy) of obtaining indicator diagrams and deepening their analysis. The usefulness of indicator diagrams can be satisfactory, unless the disturbance caused by connecting (measuring) channels is eliminated in the measurement procedure. The most frequent disturbances generated by measuring channels are:

- delay of the pressure impulse due to the time required for the pressure wave to pass through the channel,

- resonance oscillations of the gas column in the connecting channel,

- pressure drop acting on the transducer measuring node caused by the throttling of the flow through the channel,

- acceleration of the gas speed caused by a change in the cross section of the measuring channel.

Disturbances caused by measuring channels can be avoided by mounting a cylinder pressure transducer directly in the combustion chamber.

\section{Construction of a research stand}

The test stand is a generator set consisting of a SULZER 3AL 25/30 ship piston engine and an alternating current generator that guarantees the engine load in the full range of its power. It is a charged self-ignition piston engine with direct injection. The engine is equipped with the stationary diagnostic unit Unitest 2008, which allows measurement, recording and processing of indicated parameters including the average indicated pressure (in addition, the diagnostic system allows reading the pressure of fuel injection). The diagnostic system is equipped with high-quality pressure sensors from the renowned KISTLER 5363 A24 company, which are dedicated to the measurement of fast-changing cylinder pressures of four-stroke marine piston engines. In order to eliminate measurement disturbances caused by measuring channels, it was decided to install a pressure sensor in the cylinder liner flange (Fig. 2), (p3 - the place of mounting the pressure sensor in the cylinder flange). The choice of the location of the pressure sensor was not accidental. The author wanted to install the sensor in a place in the cylinder liner so that it would be exposed as low as possible to the high temperature produced by burning the fuel-air mixture. Therefore, the selected location of the pressure sensor is the cylinder liner flange, and basically its fragment, on the side of the intake air valve position.

\section{Plan and purpose of the research}

The main task of the conducted research was to look for possibilities to improve the quality (accuracy) of the indicator diagrams by comparing cylinder pressure measurements carried out in three different measurement locations. One of these measurements is carried out directly in the combustion chamber, thus omitting the influence of the measuring channel and the indicator cock. The above should contribute to the improvement of the diagnostic usefulness of indicated parameters. The research carried out so far has been divided into preliminary research and proper research. The main purpose of preliminary tests was to prepare a test stand (Fig. 2) and to determine the highest average temperature value at the place of assembly of the p3 pressure sensor. Initial tests involved in measuring the maximum average temperature at the place of 
assembly of the pressure sensor in a wide range of loads and with simulated faults. The highest temperature obtained was $295^{\circ} \mathrm{C}$, while the temperature given by the manufacturer of pressure sensors is $350^{\circ} \mathrm{C}$. It follows from the above that it is possible to use the currently used pressure sensors to measure the combustion pressure directly in the combustion chamber. Selected results of the temperature measurements are presented in Fig. 1.

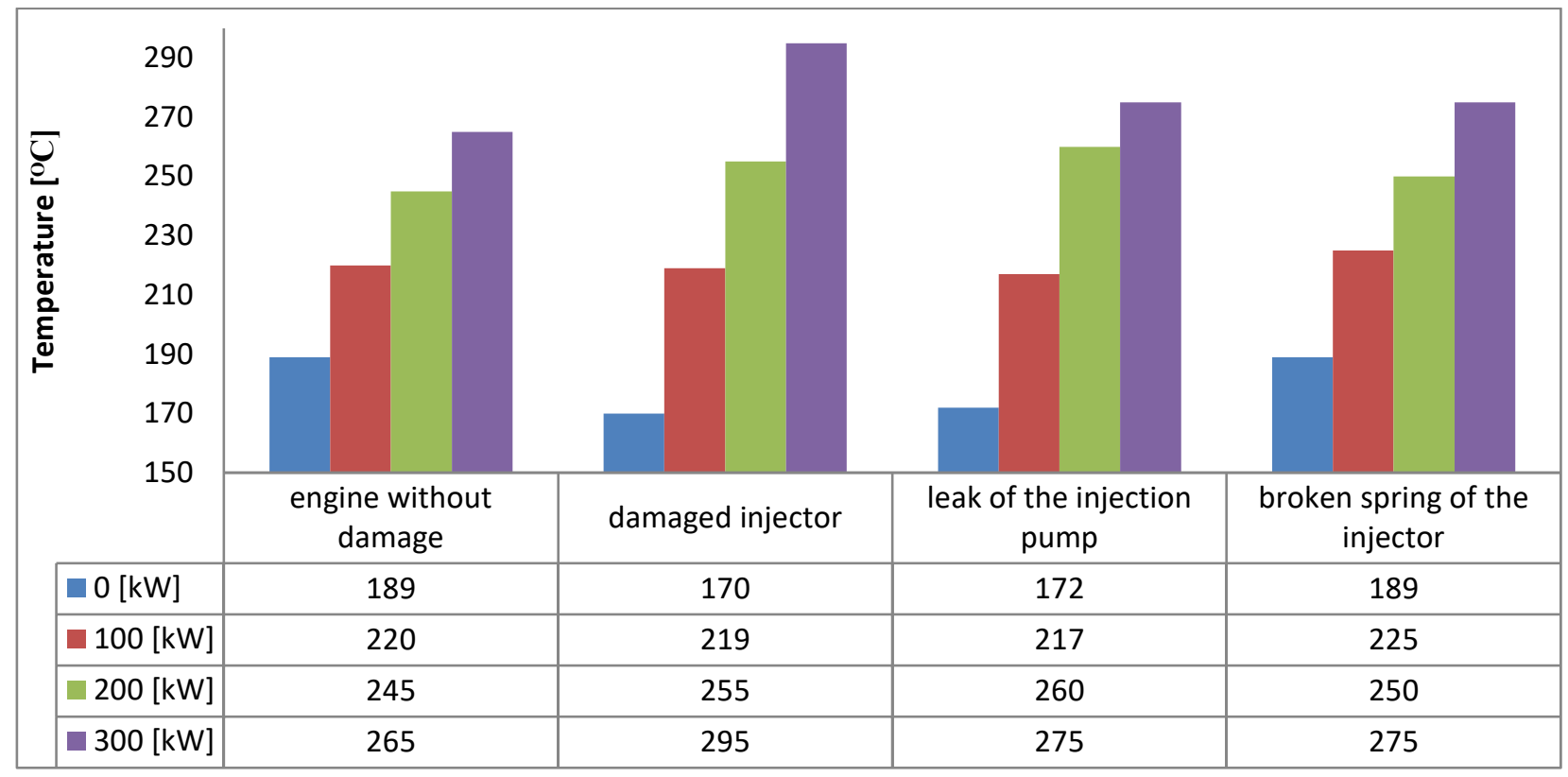

Fig. 1. Average temperature values obtained during preliminary tests for selected damage
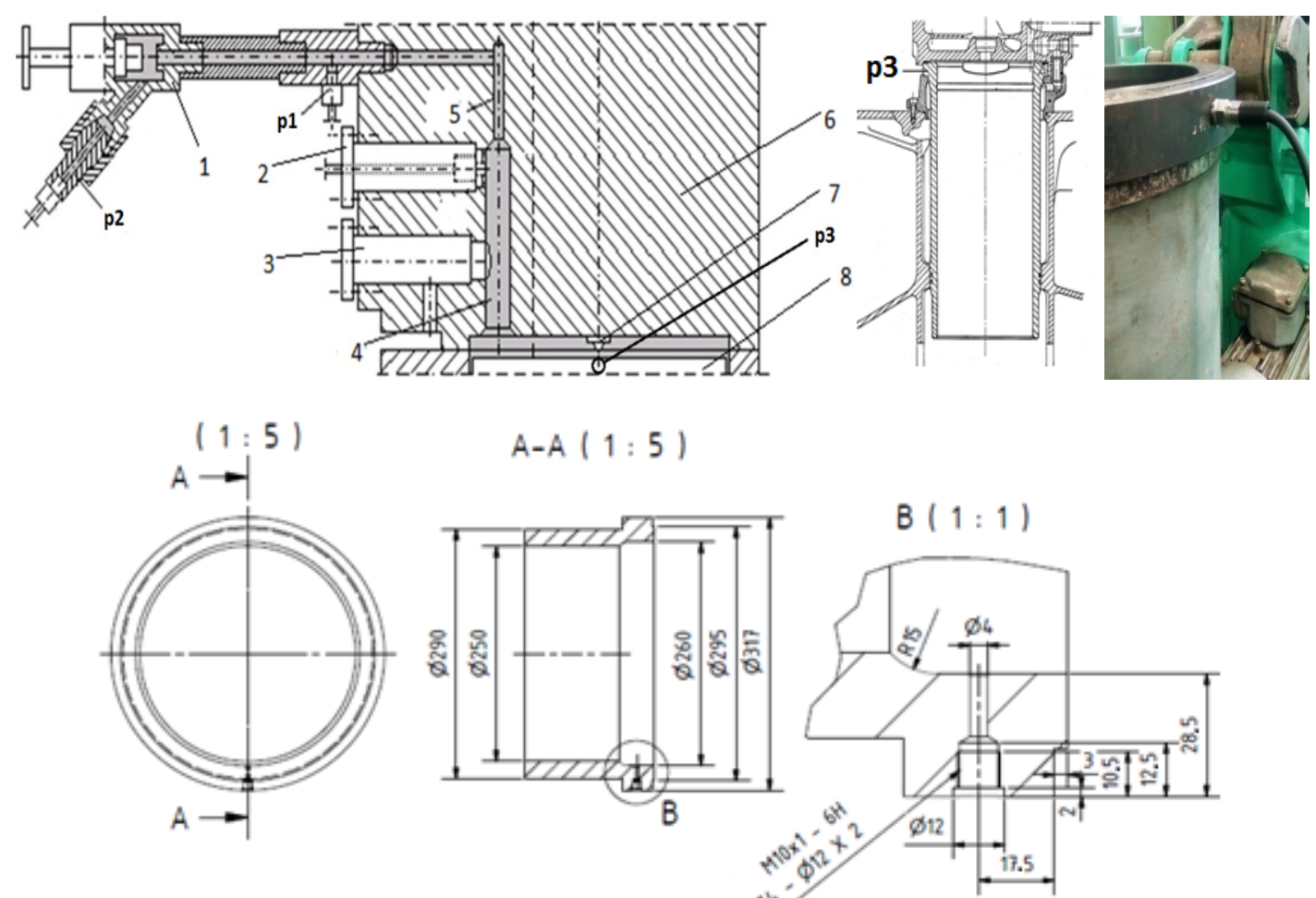

Fig. 2. Location and method of mounting cylinder pressure sensors: p1 - sensor mounted in a special adapter between the indicator valve and the connecting channel, p2 - pressure sensor mounted after the indicator valve, p3 - pressure sensor mounted in the prepared mounting hole of the cylinder liner flange, 1 -indicator valve, 2 - start valve,

3 -safety valve, 4, 5 - connecting (measuring) channel in the cylinder head, 6-cylinder head, 7 -fuel injector, 8 - combustion chamber 
Proper research consisted of simultaneous measurement of cylinder pressure at three different points of the first engine cylinder. The location of the pressure sensors is illustrated in Fig. 2 (p1 sensor mounted in a special adapter between the indicator valve and the connecting channel, $\mathrm{p} 2$ pressure sensor mounted on the indicator valve thread, this is the assembly place most often used during cylinder pressure measurements in operating conditions, $\mathrm{p} 3$ - pressure sensor mounted in a specially prepared mounting hole for cylinder liner flange). Cylinder pressure measurements were carried out at various loads: $15 \%, 30 \%, 45 \%, 60 \%$ and $75 \%$ of the rated engine power. The tests were carried out for the engine without simulated damage and with simulated damage in the fuel injection system.

\section{Test results}

Cylindrical pressure measurements were read using the Unitest 2008 measuring and recording device. The research model was a Sulzer 3AL25/30 piston engine, loaded with an alternating current generator in a wide range of loads, during which the following simulations were carried out: S1 - engine without simulated damage, S2 - engine with simulated injection pump damage, overflow valve opened by 0.125 rotations, S3 - engine with simulated injection pump damage, overflow valve opened by 0.25 revolutions, $\mathrm{S} 4$ - engine with simulated injector damage, blocked four of nine holes spray. Below the courses of cylinder pressure changes recorded at three measuring points for the engine load of $75 \% \mathrm{~N}_{\mathrm{n}}$ and for a technical engine with efficient and simulated faults in the fuel injection system are presented. The results of cylinder pressure with smaller loads have been omitted from the article. The position of the top dead centre of the piston (TDC) was carried out by determining the first derivative of the compression course of the first cylinder. For each pressure waveform read from three pressure sensors located in three different measurement locations, TDC positioning was carried out individually. For approximation (smoothing) of cylinder pressure curves, approximation of a moving 3-degree polynomial to three steps without column rewriting was used. The width of the approximation interval for each run was constant. The position of TDC presented on the graphs corresponds to $180^{\circ}$ crankshaft angle (CA).

Figures 3, 4 and 5 present the pressure waveforms recorded by the sensors at individual pressure sensor mounting locations. Four damage simulations were applied on each of them. The greatest distortion of cylinder pressure curves was observed when the pressure measurement was carried out on the tap indicator thread - p2 (Fig. 4) despite using the same approximation interval.

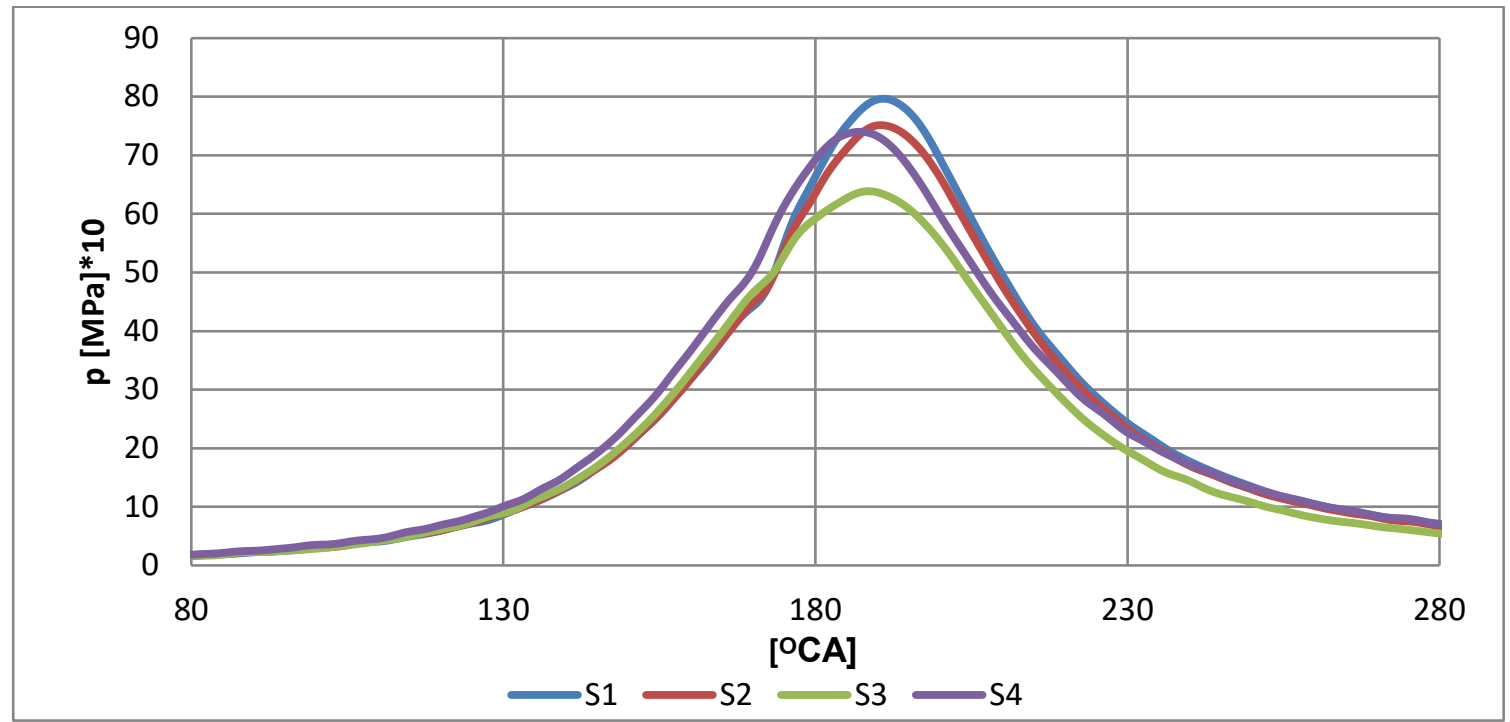

Fig. 3. Sequence of combustion pressure at $75 \% N_{n}$ load of the engine without damage Sli with simulated faults in the fuel injection system $S 2, S 3, S 4$, read in the flange of the cylinder liner p3 


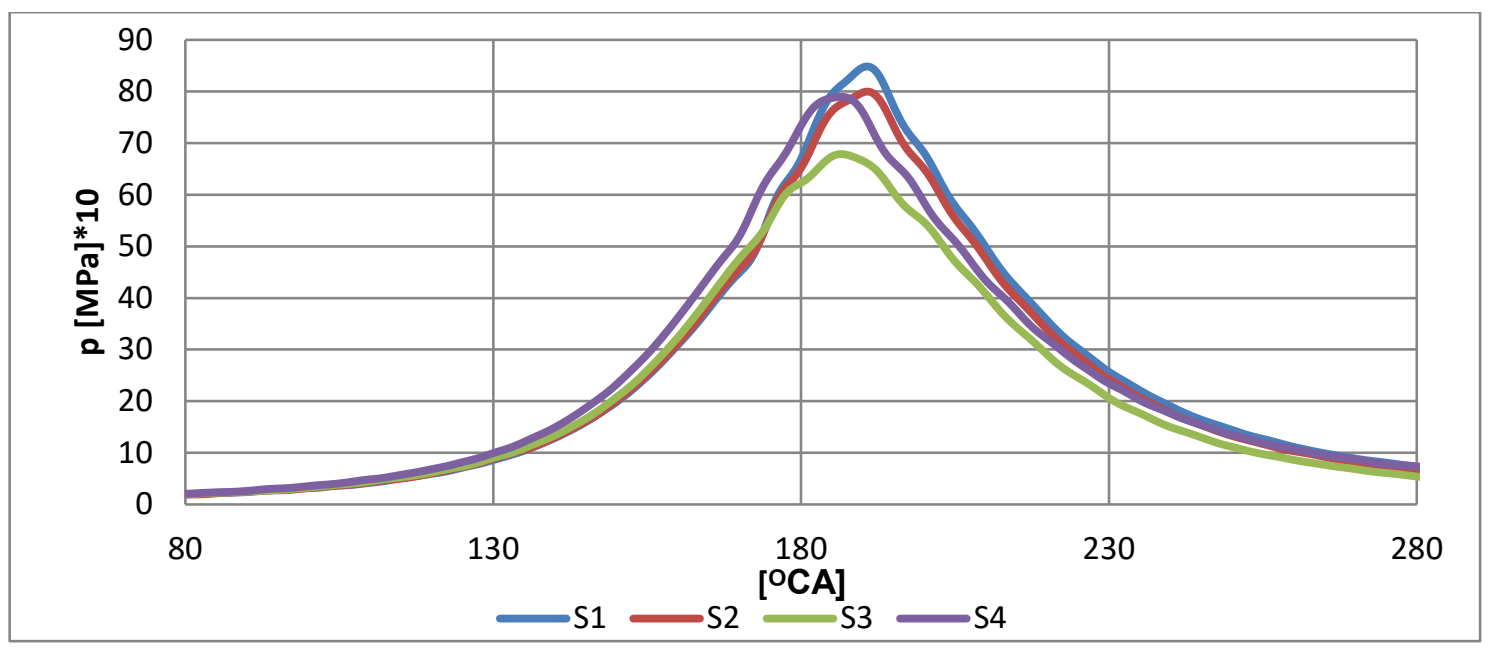

Fig. 4. Sequence of combustion pressure at $75 \% N_{n}$ load of the engine without damage S1 and with simulated faults in the fuel injection system $S 2, S 3, S 4$, read on the indicator tap $p 2$

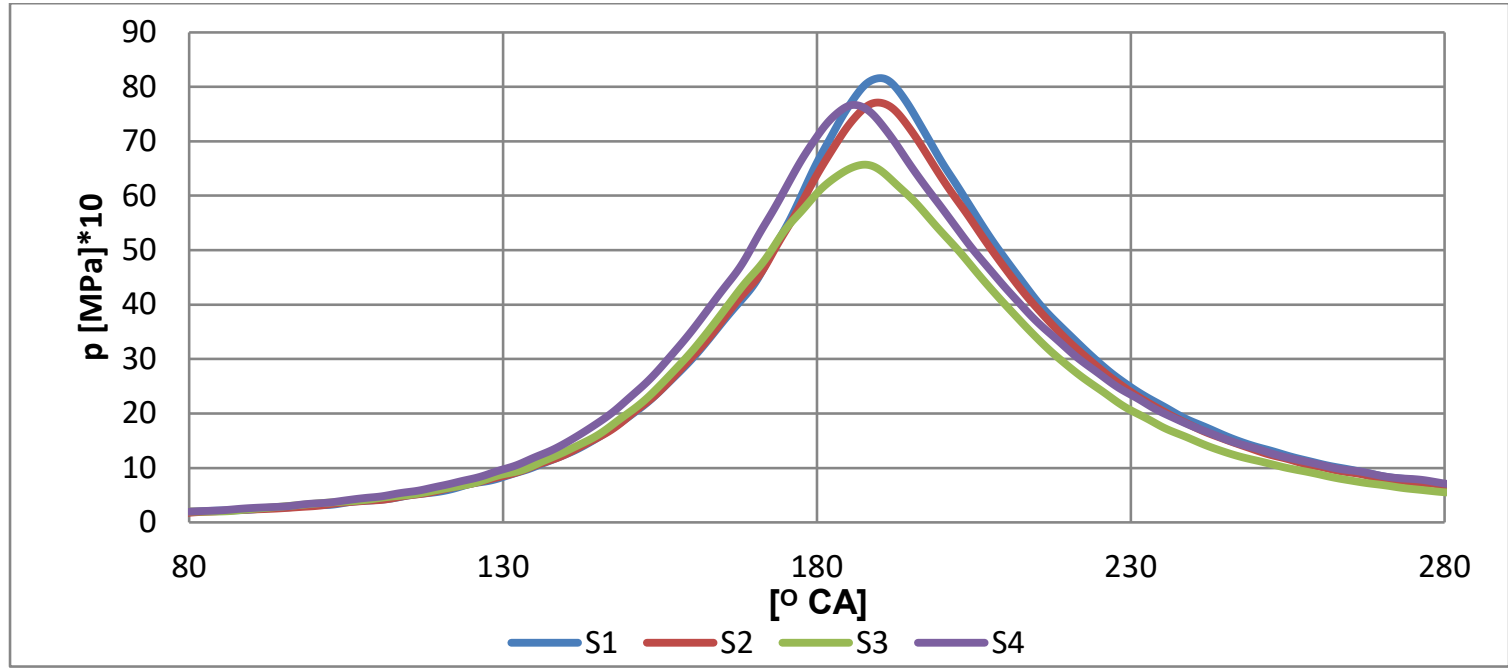

Fig. 5. Sequence of combustion pressure at $75 \% N_{n}$ load of the engine without damage S1 and with simulated faults in the fuel injection system S2, S3, S4, read between the indicator cock and the measuring channel in the cylinder head $p 1$

Crankshaft angle $\left({ }^{\circ} \mathrm{CA}\right.$ ) values (Fig. 6) for the maximum combustion pressure were read to the nearest 0.1 -degree CA. These values are set on the basis of its own dead top piston position (TDC), i.e. for each cylinder pressure measurement at three different points: p3, p2 and p1, the indicator graph was adjusted basing on its own course of the first derivative of "clean" compression. For this reason, the values of ${ }^{\circ} \mathrm{CA}$ occurring at $\mathrm{p}_{\max }$ are slightly different for a technically functional engine. The introduced simulations cause that the angular values change significantly, especially in the S3 simulation (it is a "pathological" simulation of injection pump damage).

Table 1 presents the values of the middle indicated pressure (MIP) and maximum combustion pressure $\left(\mathrm{p}_{\max }\right)$, read simultaneously, using three sensors mounted in three different measuring points. Pressure values MIP and $p_{\max }$ were first averaged from sixteen motor cycles, followed by approximation in the aforementioned manner. Cylinder pressure measurement takes place every $0.5^{\circ} \mathrm{CA}$, which are 23040 samples for one cylinder pressure measurement. Although $\mathrm{p}_{\max }$ is the smallest one for all the considered cases, MIP takes intermediate values (MIP p1 <MIP p3 $>$ MIP $\mathrm{p} 2$ ). Both the $\mathrm{p}_{\max }$ value and the shape of the combustion pressure curve influence both the MIP value. The results of MIP measurements (Tab. 1) show that the indicator tap effect has the greatest influence on the measurement result of the indicated parameters. 


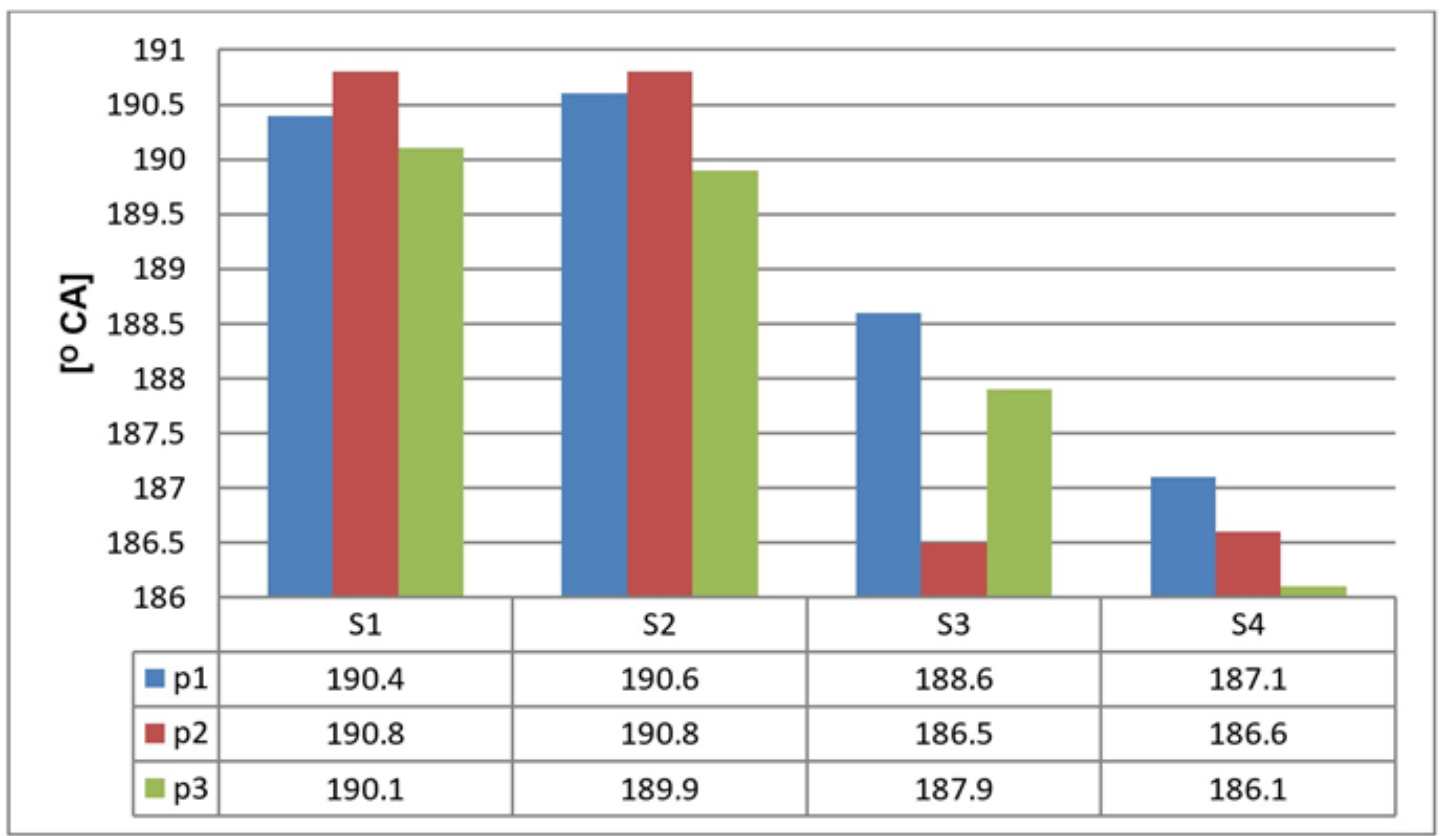

Fig. 6. Values of the angle of rotation of the crankshaft at the occurrence of the maximum combustion pressure for simulated engine damage, load $75 \% N_{n}$

Tab. 1. Values of maximum combustion pressure $p_{\max }$ and middle indicated pressure (MIP) read from pressure sensors mounted at three measuring points at engine load $75 \% N_{n}$, for simulated engine damage S1, S2, S3, and S4

\begin{tabular}{|c|c|c|c|c|c|c|c|c|}
\hline \multirow{2}{*}{} & \multicolumn{2}{|c|}{$\mathrm{S} 1$} & \multicolumn{2}{c|}{$\mathrm{S} 2$} & \multicolumn{2}{c|}{$\mathrm{S} 3$} & \multicolumn{2}{c|}{$\mathrm{S} 4$} \\
\cline { 2 - 9 } & MIP & $\mathrm{p}_{\max }$ & MIP & $\mathrm{p}_{\max }$ & MIP & $\mathrm{p}_{\max }$ & MIP & $\mathrm{p}_{\max }$ \\
\cline { 2 - 9 } & \multicolumn{9}{|c|}{$[\mathrm{MPa}]^{*} 10$} \\
\hline $\mathrm{p} 1$ & 14.934 & 81.602 & 14.454 & 77.108 & 13.085 & 65.705 & 14.918 & 76.680 \\
\hline $\mathrm{p} 2$ & 15.335 & 84.83 & 14.804 & 79.961 & 13.333 & 67.875 & 15.216 & 78.944 \\
\hline $\mathrm{p} 3$ & 15.023 & 79.658 & 14.594 & 75.134 & 13.033 & 63.874 & 14.983 & 74.012 \\
\hline
\end{tabular}

Table 2 shows the rate of combustion pressure increase $\Delta \mathrm{p} / \Delta \alpha$ in $\mathrm{MPa}$ on the degree of crankshaft rotation $\left[\mathrm{MPa} /{ }^{\circ} \mathrm{CA}\right]$, for three compartments, with the engine load of $75 \% \mathrm{~N}_{\mathrm{n}}$ and simulations S1, S2, S3 and S4. The first interval is between the twenties and tenth ${ }^{\circ} \mathrm{CA}$ before TDC, the second interval is the period from tenth ${ }^{\circ} \mathrm{CA}$ to TDC, while the third is $5^{\circ}$ before TDC up to $5^{\circ}$ for TDC. When analysing the results in Tab. 2 , it can be concluded that the $\Delta \mathrm{p} / \Delta \alpha$ parameter is the smallest for a technically efficient engine and with fault simulations for measurement in $\mathrm{p} 3$.

\section{Conclusions}

The tests carried out on the engine without simulated damages and injuries of the injector and the injection pump showed that: the size and geometry of measurement channels affect the shape of indicator diagrams and calculated parameters (registered cylinder pressures in the sleeve flange are characterized by the lowest $p_{\max }$ values and MIP then have higher values in relation to the pressure measurement at the remaining points); this is important when calculating the power from the cylinder. The above results from a significant shift of TDC "to the left" on the indicator diagram, which is primarily visible when simulating the damage to the injector.

Cylinder pressures measured in the cylinder liner flange have less interference than those measured with sensors mounted on and before the indicator valve.

The introduced simulation of a damaged injector and injection pump has an influence on the obtained measurement results, different depending on the measurement point - this applies both to the registered cylinder pressure course as well as to the read and calculated indicative parameters. 
Tab. 2. Velocity of combustion pressure increment for one degree of rotation of the crankshaft

\begin{tabular}{|c|c|c|c|c|c|c|}
\hline & \multicolumn{3}{|c|}{ S1 - without damages } & \multicolumn{3}{|c|}{ S4 - damaged injector } \\
\hline & $\begin{array}{c}20^{\circ}-10^{\circ} \\
\text { before TDC }\end{array}$ & $\begin{array}{c}10^{\circ}-0^{\circ} \\
\text { before TDC }\end{array}$ & $\begin{array}{c}5^{\circ} \text { before and } \\
5^{\circ} \text { behind TDC }\end{array}$ & $\begin{array}{c}20^{\circ}-10^{\circ} \\
\text { before TDC }\end{array}$ & $\begin{array}{c}10^{\circ}-0^{\circ} \\
\text { before TDC }\end{array}$ & $\begin{array}{c}5^{\circ} \text { before and } \\
5^{\circ} \text { behind TDC }\end{array}$ \\
\hline & \multicolumn{6}{|c|}{$\Delta \mathrm{p} / \Delta \alpha\left[\mathrm{MPa} /{ }^{\circ} \mathrm{CA}\right]$} \\
\hline $\mathrm{p} 1$ & 1.388 & 2.137 & 2.178 & 1.644 & 2.039 & 1.438 \\
\hline $\mathrm{p} 2$ & 1.426 & 2.229 & 2.226 & 1.556 & 2.107 & 1.611 \\
\hline \multirow[t]{4}{*}{ p3 } & 1.258 & 2.142 & 1.848 & 1.3 & 2.03 & 1.086 \\
\hline & \multicolumn{3}{|c|}{$\begin{array}{c}\text { S2 - damaged injection pump } \\
0.125\end{array}$} & \multicolumn{3}{|c|}{$\begin{array}{c}\text { S3 - damaged injection pump } \\
0.25\end{array}$} \\
\hline & $\begin{array}{c}20^{\circ}-10^{\circ} \\
\text { before TDC }\end{array}$ & $\begin{array}{c}10^{\circ}-0^{\circ} \\
\text { before TDC }\end{array}$ & $\begin{array}{c}5^{\circ} \text { before and } \\
5^{\circ} \text { behind TDC }\end{array}$ & $\begin{array}{c}20^{\circ}-10^{\circ} \\
\text { before TDC }\end{array}$ & $\begin{array}{c}10^{\circ}-0^{\circ} \\
\text { before TDC }\end{array}$ & $\begin{array}{c}5^{\circ} \text { before and } \\
5^{\circ} \text { behind TDC }\end{array}$ \\
\hline & \multicolumn{6}{|c|}{$\Delta \mathrm{p} / \Delta \alpha\left[\mathrm{Mpa} /{ }^{\circ} \mathrm{CA}\right]$} \\
\hline $\mathrm{p} 1$ & 1.425 & 1.888 & 1.803 & 1.406 & 1.476 & 1.075 \\
\hline $\mathrm{p} 2$ & 1.455 & 1.908 & 1.162 & 1.499 & 1.45 & 1.226 \\
\hline $\mathrm{p} 3$ & 1.321 & 1.71 & 1.316 & 1.346 & 1.305 & 1.012 \\
\hline
\end{tabular}

Further in-depth analysis of indicator diagrams and parameters indicated with the use of pressure measurement directly in the combustion chamber is necessary, also with the use of derivative of pressure waveforms and heat release function.

The article presents combustion pressure curves with TDC determination based on the course of the first derivative of the pressure course for each of the pressure sensors; if we relate TDC positioning to one of the measurement sites, the $\mathrm{p}_{\max }$ and MIP results and the pressure curves recorded with the other sensors would be significantly different from those described above, which will be the subject of further research.

\section{References}

[1] Cupiał, K., Dużyński, A., Gruca, M., Grzelka, J., Some errors of gas engine indication, Journal of KONES, Vol. 8, No. 1-2, 2001.

[2] Gałecki, W., Tomczak, L., Indykowanie okrętowych silników spalinowych, Akademia Morska, Dział Wydawnictw, Gdynia 2002.

[3] Instrukcja obstugi programu Unitest 2008, Gdynia 2009.

[4] KISTLER, materiaty informacyjno-reklamowe firmy, https://www.kistler.com/en/.

[5] Piotrowski, I., Witkowski, K., Okrętowe silniki spalinowe, Trademar, Wyd. 3a, Gdynia 2003.

[6] Polanowski, S., Studium metod analizy wykresów indykatorowych $w$ aspekcie diagnostyki silników okrętowych, Zeszyty Naukowe Akademii Marynarki Wojennej w Gdyni, Nr 169A, Gdynia 2007.

[7] Polanowski, S., Pawletko, R., Witkowski, K., Influence of pressure sensor location on the quality of thermodynamic parameters calculated from the marine engine indicator diagram, Combustion Engines, Vol. 154 (3), pp. 319-323, 2013.

[8] Tomczak, L., Wykorzystanie pośredniej metody określania położenia watu korbowego w indykatorze elektronicznym, praca doktorska, Politechnika Gdańska, Wydział Mechaniczny, Gdansk 2001.

[9] Unitest, materiaty informacyjno-reklamowe firmy, http://www.unitest.pl/.

[10] Wajand, J., Pomiary szybkozmiennych ciśnień w maszynach tłokowych, Wydawnictwo Naukowo-Techniczne, Warszawa 1974. 
[11] Witkowski, K., Wykorzystanie analizy charakterystyk wydzielania ciepła do oceny stanu technicznego aparatury wtryskowej silnika okrętowego, Wydawnictwo Politechniki Poznańskiej, Rozprawy, Nr 490, Poznan 2013.

[12] Wysocki, J., Modyfikacja układu do pomiaru przebiegu ciśnienia spalania okrętowego silnika tłokowego Sulzer AL25/30, Zeszyty Naukowe Akademii Morskiej w Gdyni, Nr 108, s. 168-180, Gdynia 2018.

Manuscript received 21 March 2019; approved for printing 25 June 2019 